\title{
Trends of rainfall and temperature in Northeast Brazil
}

\author{
Ailton A. de Carvalho' ${ }^{1}$, Abelardo A. de A. Montenegro ${ }^{1}$, Hernande P. da Silva ${ }^{1}$, Iug Lopes ${ }^{1}$, \\ José E. F. de Morais ${ }^{1} \&$ Thieres G. F. da Silva²
} ${ }^{1}$ Universidade Federal Rural de Pernambuco/Departamento de Engenharia Agrícola/Programa de Pós-Graduação em Engenharia Agrícola. Recife, PE,
Brasil. E-mail: ailtonalvesst@hotmail.com (Corresponding author) - ORCID: 0000-0001-8783-649X; abelardomontenegro666@gmail.com - ORCID:
0000-0002-5746-8574; hernandepereira@yahoo.com.br - ORCID: 0000-0002-2040-6994; iuglopes@hotmail.com - ORCID: 0000-0003-0592-4774;
joseedson50@hotmail.com - ORCID: 0000-0002-3641-2221
${ }^{2}$ Universidade Federal Rural de Pernambuco/Unidade Acadêmica de Serra Talhada/Departamento de Agronomia. Serra Talhada, PE, Brasil. E-mail:
thigeoprofssional@hotmail.com - ORCID: 0000-0002-8355-4935

\begin{abstract}
For climate change scenarios, there is a high degree of complexity, with impacts on the future availability of water resources. In this context, studies related to changes in rainfall time series are essential in order to identify environmental vulnerability. The objective of this study was to analyze trends in the rainfall regime, number of rainy days and temperature for stations located at different continentality and altitude conditions in Northeast Brazil. Meteorological data of the Instituto Nacional de Meteorologia were used, being classified according to the location in relation to the continent: coastal strip (14 stations), strip of $150-300 \mathrm{~km}$ up to $300 \mathrm{~m}$ altitude (14 stations) and above $300 \mathrm{~m}$ (five stations), between 400 and $600 \mathrm{~km}$ from the coast up to $300 \mathrm{~m}$ (four stations) and above $300 \mathrm{~m}$ (eight stations). All the 45 stations used have a historical series with a data period of more than 30 years. The trend of rainfall and rainy days was obtained through the Mann-Kendall and regression analyses, at significance levels of 0.01 and 0.05 , respectively. There were trends of reduction in the number of rainy days, in the coastal strip, as well as reduction in rainfall and rainy days, both in the strip of 150-300 km from the coast and in the Sertão region, with no significant effect of continentality in the strip of 400-600 km from the coast. For temperature, except for Maceió, AL, Brazil, there is a trend of increase in near future.
\end{abstract}

Key words: continentality, rainfall modeling, climate variability

\section{Tendências da precipitação pluvial e da temperatura no Nordeste brasileiro}

RESUMO: Nos cenários de mudanças climáticas verifica-se elevada complexidade, estando previstos impactos na disponibilidade futura de recursos hídricos. Nesse contexto, estudos relacionados às alterações nas séries temporais do regime pluvial são essenciais para identificar a vulnerabilidade ambiental. Assim, objetivouse analisar as tendências no regime pluvial, no número de dias de precipitação e temperatura em estações situadas em diferentes condições de continentalidade e altitude no Nordeste brasileiro. Foram utilizados dados meteorológicos do Instituto Nacional de Meteorologia, sendo classificados de acordo a faixa de localização em relação ao continente: faixa litorânea (14 estações), na faixa de $150-300 \mathrm{~km}$ até $300 \mathrm{~m}$ de altitude (14 estações) e acima de $300 \mathrm{~m}$ (cinco estações), entre 400 e $600 \mathrm{~km}$ do litoral até $300 \mathrm{~m}$ (quatro estações) e acima de $300 \mathrm{~m}$ (8 estações). Todas as 45 estações utilizadas possuem série histórica com período de dados superior a 30 anos. A tendência da precipitação e dias de chuva foi investigada através da análise Mann-Kendall e de regressão, para os níveis de significância de 0,01 e 0,05, respectivamente. Foram identificadas tendências de redução no número de dias de precipitação, na faixa litorânea, bem como redução na precipitação e nos dias com chuva, tanto na faixa de 150 a $300 \mathrm{~km}$ do litoral, quanto na região do Sertão, não havendo efeito significativo da continentalidade na faixa de 400 a $600 \mathrm{~km}$ do litoral. Para a temperatura, com exceção de Maceió, AL, Brasil, observa-se tendência de incremento em futuro próximo.

Palavras-chave: continentalidade, modelagem da precipitação, variabilidade climática 


\section{INTRODUCTION}

Severe droughts and floods are phenomena related to rainfall variability and can significantly affect agricultural production and the environment, particularly in arid and semiarid regions (Pinheiro et al., 2013; Sun \& Ma, 2015).

The Intergovernmental Panel on Climate Change (IPCC, 2013) emphasizes that global warming has caused higher variability in rainfall regimes. This fact has been observed in the rainfall regimes in Brazil and worldwide, induced by the occurrence of extreme natural phenomena (Carretas, 2014).

Marcuzzo et al. (2012) analyzed data from 37 pluviometric stations with 30 years of data in the state of Goiás, Brazil, and observed that every month had a variation greater than the annual average, indicating greater dispersion. Pingale et al. (2014), investigating the trend of rainfall in 33 cities in the semiarid region of Rajasthan, India, found positive and negative trends.

Montenegro \& Ragab (2010) found that the increase in temperature and the greater temporal variability in rainfall caused changes in the availability of water resources, leading to the reduction of surface runoff and recharge.

Evaluations of trends in rainfall regimes are essential in agricultural planning and preservation of ecosystems (Back et al., 2012), since rainfall is the climatic variable with highest spatial-temporal variability, conditioned to the factors of altitude, latitude, continentality and the dynamics of air masses in the atmosphere (Buriol et al., 2004).

Thus, this study aimed to analyze trends in the total annual rainfall, number of rainy days and temperature under different conditions of continentality and altitude in Northeast Brazil.

\section{Material And Methods}

The area of this study is the Northeast region of Brazil, where records of daily rainfall and number of rainy days (NRD) were analyzed in the pluviometric stations of the Instituto Nacional de Meteorologia (INMET, 2018). The meteorological stations were organized in relation to the distance from the coast and according to the altitude intervals.

Stations of the coastal region, in the strip of 150-300 km up to $300 \mathrm{~m}$ altitude (14 stations) and above $300 \mathrm{~m}$ (five stations), between 400 and $600 \mathrm{~km}$ from the coast up to $300 \mathrm{~m}$ (four stations) and above $300 \mathrm{~m}$ ( 8 stations) (Table 1) were selected, obeying the continuity and with a minimum period of records of 30 years of data as recommended by WMO (1989).

A descriptive statistical analysis of central tendency (mean), dispersion (coefficient of variation) and adherence to normal

Table 1. Geographic location and descriptive statistics of the stations analyzed in the Northeast region

\begin{tabular}{|c|c|c|c|c|c|c|c|c|c|c|}
\hline \multirow[b]{2}{*}{ ID } & \multirow[b]{2}{*}{ Station } & Latitude & Longitude & \multirow{2}{*}{$\begin{array}{l}\text { Altitude } \\
\text { (m) }\end{array}$} & \multicolumn{2}{|c|}{ Annual rainfall } & \multicolumn{2}{|c|}{ NRD } & \multicolumn{2}{|c|}{ Temperature } \\
\hline & & \multicolumn{2}{|c|}{$\left({ }^{\circ}\right)$} & & $\begin{array}{c}\text { Mean } \\
\left.\text { (mm year }{ }^{-1}\right)\end{array}$ & CV (\%) & $\begin{array}{c}\text { Mean } \\
\left(n^{\circ} \text { days }\right)\end{array}$ & CV $(\%)$ & $\begin{array}{l}\text { Mean } \\
\left({ }^{\circ} \mathrm{C}\right)\end{array}$ & CV $(\%)$ \\
\hline \multicolumn{11}{|c|}{ Coastal region } \\
\hline 1 & Aracajú - SE & -10.95 & -37.04 & 16.5 & 1144 & 52.5 & 109 & 27.5 & 27.1 & 2.6 \\
\hline 2 & Canavieiras - BA & -15.66 & -38.95 & 3.9 & 1688 & 26.7 & 176 & 23.9 & 24.7 & 1.8 \\
\hline 3 & Caravelas - BA & -17.73 & -39.25 & 2.9 & 1347 & 21.3 & 168 & 14.3 & 25.5 & 1.8 \\
\hline 4 & Fortaleza - CE & -3.81 & -38.53 & 26.5 & 1613 & 34.8 & 161 & 19.3 & 26.8 & 1.6 \\
\hline 5 & João Pessoa - PB & -7.10 & -34.86 & 7.4 & 1917 & 32.5 & 183 & 18.6 & 26.5 & 2.1 \\
\hline 6 & Macau - RN & -5.15 & -36.57 & 32.0 & 573 & 42.6 & 64 & 32.8 & 27.4 & 2.7 \\
\hline 7 & Maceió - AL & -9.66 & -35.70 & 64.5 & 1952 & 23.9 & 206 & 17.5 & 25.3 & 2.6 \\
\hline 8 & Natal - RN & -5.91 & -35.20 & 48.6 & 1620 & 28.6 & 161 & 16.2 & 26.3 & 1.8 \\
\hline 9 & Parnaíba - PI & -3.08 & -41.76 & 79.5 & 1229 & 47.2 & 106 & 27.4 & 27.0 & 2.3 \\
\hline 10 & Porto de Pedras - AL & -9.18 & -35.43 & 50.0 & 1782 & 20.7 & 190 & 14.7 & 26.1 & 1.8 \\
\hline 11 & Recife - PE & -8.05 & -34.95 & 10.0 & 2291 & 21.8 & 218 & 8.7 & 25.7 & 1.5 \\
\hline 12 & Salvador -BA & -13.01 & -38.53 & 51.4 & 1944 & 23.1 & 201 & 13.4 & 25.5 & 1.7 \\
\hline 13 & São Luiz - MA & -2.53 & -44.21 & 50.9 & 2267 & 26.8 & 140 & 20.7 & 26.6 & 2.1 \\
\hline 14 & Turiaçu - MA & -1.56 & -45.36 & 44.1 & 2207 & 25.6 & 159 & 18.9 & 26.9 & 1.8 \\
\hline \multicolumn{11}{|c|}{150 to $300 \mathrm{~km}$ away from the coast (up to $300 \mathrm{~m}$ altitude) } \\
\hline 15 & Bacabal - MA & -4.21 & -44.76 & 25.1 & 1722 & 27.8 & 102 & 46.1 & 27.5 & 3.6 \\
\hline 16 & Caldeirão - Pl & -4.28 & -41.8 & 160.0 & 1330 & 37.9 & 85 & 40.0 & 27.4 & 2.8 \\
\hline 17 & Caxias - MA & -4.86 & -43.35 & 103.6 & 1592 & 28.7 & 97 & 29.9 & 27.4 & 2.7 \\
\hline 18 & Crateús - CE & -5.16 & -40.66 & 296.8 & 748 & 40.4 & 80 & 26.3 & 26.9 & 3.7 \\
\hline 19 & Cruzeta - RN & -6.43 & -36.58 & 226.5 & 729 & 35.7 & 61 & 44.3 & 27.1 & 2.2 \\
\hline 20 & Iguatu - CE & -6.36 & -39.29 & 217.7 & 998 & 28.6 & 80 & 31.3 & 26.9 & 2.4 \\
\hline 21 & Itaberaba - BA & -12.51 & -40.28 & 249.9 & 681 & 33.0 & 117 & 29.1 & 24.5 & 2.5 \\
\hline 22 & Patos - PB & -7.01 & -37.26 & 249.1 & 748 & 34.5 & 66 & 37.9 & 27.5 & 2.2 \\
\hline 23 & Paulo Afonso - BA & -9.36 & -38.21 & 252.7 & 544 & 32.5 & 94 & 31.9 & 25.9 & 1.9 \\
\hline 24 & Quixeramobim - CE & -5.16 & -39.28 & 79.5 & 756 & 35.2 & 86 & 29.1 & 26.8 & 4.4 \\
\hline 25 & São Gonçalo - PB & -6.75 & -38.21 & 233.1 & 926 & 37.4 & 78 & 33.3 & 26.7 & 2.7 \\
\hline 26 & Seridó (Caicó) - RN & -6.46 & -37.08 & 169.9 & 644 & 41.6 & 71 & 32.4 & 28.3 & 2.3 \\
\hline 27 & Teresina - PI & -5.08 & -42.81 & 74.4 & 1234 & 31.8 & 101 & 25.7 & 27.1 & 2.6 \\
\hline 28 & Zé Doca - MA & -3.26 & -45.65 & 45.3 & 1809 & 18.0 & 139 & 23.0 & 26.9 & 3.1 \\
\hline \multicolumn{11}{|c|}{150 to $300 \mathrm{~km}$ away from the coast (above $300 \mathrm{~m}$ altitude) } \\
\hline 29 & Água Branca - AL & -9.28 & -37.90 & 605.3 & 968 & 31.5 & 103 & 35.9 & 23.1 & 2.3 \\
\hline 30 & Arcoverde - PE & -8.41 & -37.08 & 680.7 & 651 & 35.8 & 100 & 24.0 & 23.0 & 4.0 \\
\hline 31 & Ituaçu - BA & -13.81 & -41.30 & 531.4 & 587 & 31.2 & 79 & 31.7 & 24.2 & 3.4 \\
\hline 32 & Monte Santo - BA & -10.43 & -39.29 & 464.6 & 624 & 29.3 & 111 & 22.5 & 24.1 & 3.3 \\
\hline 33 & Monteiro - PB & -7.88 & -37.06 & 603.7 & 630 & 39.4 & 64 & 31.3 & 24.2 & 2.7 \\
\hline
\end{tabular}

Continues on the next page 
Continued from Table 1

\begin{tabular}{|c|c|c|c|c|c|c|c|c|c|c|}
\hline \multirow[b]{2}{*}{ ID } & \multirow[b]{2}{*}{ Station } & Latitude & Longitude & \multirow{2}{*}{$\begin{array}{c}\text { Altitude } \\
\text { (m) }\end{array}$} & \multicolumn{2}{|c|}{ Annual rainfall } & \multicolumn{2}{|c|}{ NRD } & \multicolumn{2}{|c|}{ Temperature } \\
\hline & & \multicolumn{2}{|c|}{$\left({ }^{0}\right)$} & & $\begin{array}{c}\text { Mean } \\
\left(\mathrm{mm}^{2} \text { year }{ }^{-1}\right)\end{array}$ & CV (\%) & $\begin{array}{c}\text { Mean } \\
\left(n^{\circ} \text { days }\right)\end{array}$ & CV (\%) & $\begin{array}{l}\text { Mean } \\
\left({ }^{\circ} \mathrm{C}\right)\end{array}$ & CV (\%) \\
\hline \multicolumn{11}{|c|}{400 to $600 \mathrm{~km}$ away from the coast (up to $300 \mathrm{~m}$ altitude) } \\
\hline 34 & Balsas - MA & -7.53 & -46.03 & 259.4 & 1265 & 20.2 & 91 & 25.3 & 26.5 & 3.4 \\
\hline 35 & Floriano - PI & -6.76 & -43.01 & 123.3 & 971 & 32.2 & 96 & 20.8 & 27.7 & 3.8 \\
\hline 36 & Imperatriz - MA & -5.53 & -47.48 & 123.3 & 1473 & 21.9 & 101 & 30.7 & 26.9 & 3.2 \\
\hline 37 & Picos - PI & -7.03 & -41.48 & 207.9 & 736 & 31.4 & 74 & 28.4 & 27.8 & 4.1 \\
\hline \multicolumn{11}{|c|}{400 to $600 \mathrm{~km}$ away from the coast (above $300 \mathrm{~m}$ altitude) } \\
\hline 38 & Barra - BA & -11.08 & -43.16 & 401.6 & 661 & 30.9 & 56 & 21.4 & 26.4 & 2.9 \\
\hline 39 & Bom Jesus da Lapa - BA & -13.26 & -43.41 & 439.9 & 816 & 24.1 & 75 & 18.7 & 25.8 & 3.5 \\
\hline 40 & Carinhanha - BA & -14.28 & -43.76 & 450.2 & 802 & 25.1 & 72 & 20.8 & 25.6 & 2.6 \\
\hline 41 & Correntina - BA & -13.33 & -44.61 & 549.5 & 995 & 25.0 & 80 & 16.3 & 24.1 & 3.2 \\
\hline 42 & Ouricuri - PE & -7.90 & -40.04 & 459.3 & 614 & 41.0 & 75 & 30.7 & 25.8 & 4.5 \\
\hline 43 & Paulistana - PI & -8.13 & -41.13 & 374.2 & 571 & 40.8 & 57 & 31.6 & 26.9 & 3.6 \\
\hline 44 & Petrolina - PE & -9.38 & -40.48 & 370.5 & 472 & 38.8 & 49 & 30.6 & 26.9 & 2.6 \\
\hline 45 & Remanso - BA & -9.63 & -42.10 & 400.5 & 634 & 31.2 & 48 & 25.0 & 26.7 & 2.4 \\
\hline
\end{tabular}

NRD - Number of rainy days; CV - Coefficient of variation

distribution was performed using the Kolmogorov-Smirnov test $(\mathrm{KS})$ at $\mathrm{p} \leq 0.05$, for the records of total annual rainfall and average annual temperature, and for the number of rainy days (NRD) values.

The coefficient of variation (CV) was classified according to the criterion of Warrick \& Nielsen (1980), which considers the degree of variability as low $(\mathrm{CV}<12 \%)$, medium $(12 \leq \mathrm{CV}$ $\leq 60 \%)$ and high $(\mathrm{CV}>60 \%)$.

The geographic locations of the INMET pluviometric stations in which the trend of rainfall, NRD and temperature were evaluated are shown in Figure 1.

The studied period was from 1961 to 2017. Each rainfall series was evaluated for the trend of Total Annual Rainfall (TAR), Total Annual Number of Rainy Days (TANRD), average temperature (Temp) and NRD. Its temporal evolution was verified by means of the Deviations of Rainfall from the Mean (DRM) and of the Deviations of Rainy Days from the Mean (DRDM), in order to identify any changes in the climatological behavior over the years.

The non-parametric Mann-Kendall test is widely used to detect monotonic trends in hydrometeorological time series.

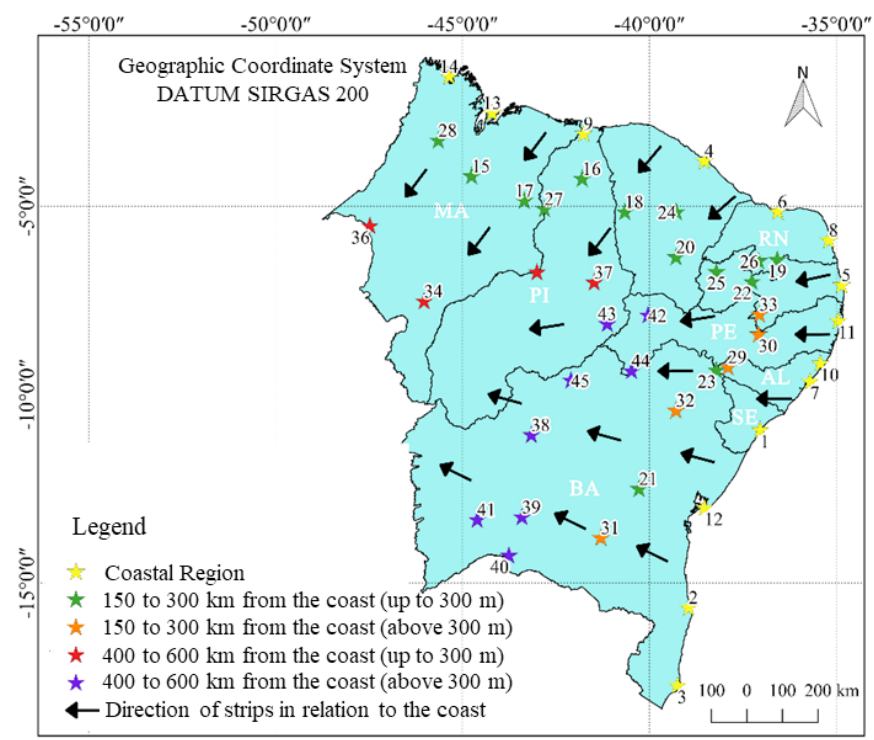

The arrows represent the direction of the analyses in relation to the coast $(150,300,400$ and $600 \mathrm{~km}$ )

Figure 1. Location of the stations in the Brazilian Northeastern states
It is based on the null hypothesis $\left(\mathrm{H}_{0}\right)$, in which the data are identically distributed (no trend), and on the alternative hypothesis $\left(\mathrm{H}_{\mathrm{A}}\right)$, in which the data follow a monotonic trend in the time series. The test confirms the existence of a positive or negative trend according to the $S$ test statistic for a given level of confidence (Pinheiro et al., 2013; Xu et al., 2018).

The test statistic (S) was applied according to the methodology of Pinheiro et al. (2013) and $\mathrm{Xu}$ et al. (2018), described by Eq. 1:

$$
\mathrm{S}=\sum_{\mathrm{k}=1}^{\mathrm{n}-1} \sum_{\mathrm{j}=\mathrm{k}+1}^{\mathrm{n}} \operatorname{sign}(\mathrm{x}(\mathrm{j})-\mathrm{x}(\mathrm{i}))
$$

where:

$x(i)$ - time series of $i=1,2,3, \ldots, n-1$;

$x(j)$ - time series of $j=i+1, \ldots, n, x(j)$ is higher than $x(i)$; and,

$\mathrm{n} \quad$ - length of the data set record.

Each point $\mathrm{x}(\mathrm{i})$ is used as the reference point of $\mathrm{x}(\mathrm{j})$, and the results are recorded as $\operatorname{sign}(\theta)(1, \theta>0 ; 0, \theta=0 ;-1, \theta<0)$.

If the data set is distributed identically and independently, then the average of $S$ is zero and the variance of $S$ is (Eq. 2):

$$
\operatorname{Var}(S)=\frac{\left[\mathrm{n}(\mathrm{n}-1)(2 \mathrm{n}+5)-\sum_{\mathrm{t}=1}^{\mathrm{q}} \mathrm{t}(\mathrm{t}-1)(2 \mathrm{t}+5)\right]}{18}
$$

where:

n - size of the data set;

$\mathrm{t}$ - number of data with values repeated within a certain group; and,

q - number of groups containing repeated values.

For a long time series, the statistical value $S$ can be transformed into $\mathrm{Z}$, according to the following conditions: $\mathrm{Z}$ $(S-1 / \sqrt{ } \operatorname{Var}(S), S>0 ; 0, S=0 ; S+1 / \sqrt{ } \operatorname{Var}(S), S<0)$. When -1.96 $\leq \mathrm{Z} \leq 1.96$, the null hypothesis $\left(\mathrm{H}_{0}\right)$ is accepted, which indicates that there is no trend in the time series. The trend is significant at 0.95 confidence level if $|Z|>1.96$, and at 0.99 confidence level if $|Z|>2.58$. A positive $Z$ value indicates that the sequence 
has an upward trend, whereas a negative $\mathrm{Z}$ reflects a downward trend (Pinheiro et al., 2013; Xu et al., 2018).

After the trends are identified, their magnitude is analyzed using the Sen curvature test (Sen, 1968), according to Eq. 3:

$$
\int \beta=\left(\frac{x_{j}-x_{k}}{j-k}\right), \text { for } i=1,2,3, \ldots, n
$$

where:

$\beta$ - Sen's slope estimator. When the values are positive, the trend is positive, and when the values are negative, the trend is negative; and,

$\mathrm{x}_{\mathrm{j}}$ and $\mathrm{x}_{\mathrm{k}}$ - are the values given at the times $\mathrm{j}$ and $\mathrm{k}(\mathrm{j}>\mathrm{k})$, respectively.

The behavior of the annual time series of meteorological variables was evaluated by adopting the calculation of the moving averages, employing the order five for the data, aiming to avoid fluctuations and smoothing the data (Ferreira et al., 2015).

Future projection for rainfall and NRD was then carried out for the next 30 years based on the Mann-Kendall trend analysis and the $\beta$ (Sen's slope) coefficient, up to 2047 , assuming that no significant change will occur on the climate variability patterns in near future.

For geostatistical analysis, the classical statistical estimator of semivariance was adopted. After obtaining the semivariances, the Gaussian, spherical and exponential models were tested, and the one which best fitted to the experimental values according to the cross-validation and which produced standardized errors close to zero was chosen, according to Jackknifing criterion (Montenegro \& Montenegro, 2006).

From the fit of the semivariograms, the spatial distribution analysis was performed through the Kriging method in order to map the climatic variables correlated in space (Montenegro \& Montenegro, 2006), for the variables rainfall, number of rainy days and temperature.

The degree of spatial dependence was based on Cambardella et al. (1994), according to the following classification: strong (less than 25\%), moderate (between 25 and 75\%) or weak (above 75\%) spatial dependence.

\section{Results AND Discussion}

The trends of Total Annual Rainfall (TAR), Total Annual Number of Rainy Days (TANRD), Mean temperature (Temp), Deviations of Rainfall from the Mean (DRM), Deviations of Rainy Days from the Mean (DRDM) and the respective $\mathrm{Z}$ values of the coastal strip of Northeast Brazil are presented in Figure 2.

The station of Parnaíba, PI, was the only one which showed a trend of reduction in TAR, with an estimated value of $118 \mathrm{~mm}$ for 30 years. The others had a trend of reduction for NRD in Caravelas, BA (23 days), Salvador, BA (17 days), Fortaleza, CE (19 days), Maceió, AL (28 days) and Canavieiras, BA (29 days).
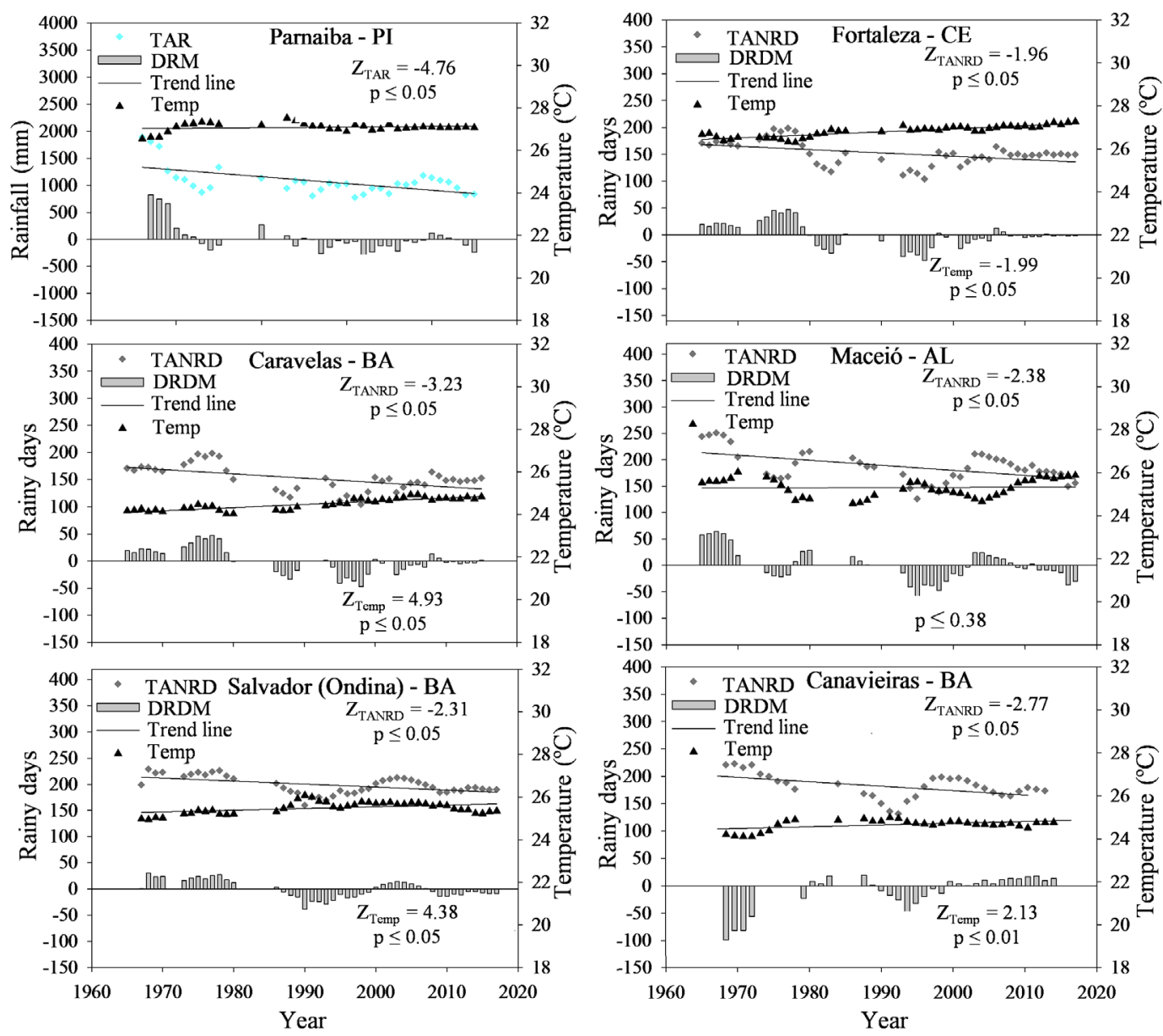

Figure 2. Trend of rainfall (TAR), total annual number of rainy days (TANRD), temperature (Temp), deviations of rainfall from the mean (DRM) and Z values for the coastal strip of Northeast Brazil between 1961 and 2017 
Except for Maceió, AL, a trend of increase in the temperature was observed. These changes in the temperature pattern, according to Fall et al. (2011), may be associated with human activities, particularly related to excessive emissions of greenhouse gases, from agriculture, livestock farming and industry, regarded as the main cause of global warming (Mahlstein \& Knutti, 2010).

The reductions in TANRD represent a higher concentration of rainfall, consequently resulting in the increase of its intensity and, therefore, in major damage risk to urban and rural environments, possibly increasing of floods events and soil degradation.

According to Silva et al. (2012), intense rainfall can aggravate erosion processes in the semiarid region in areas with shallow soils and with restricted natural drainage. In addition, knowledge on rainfall trend is important for the analysis of environmental impacts and dimensioning of

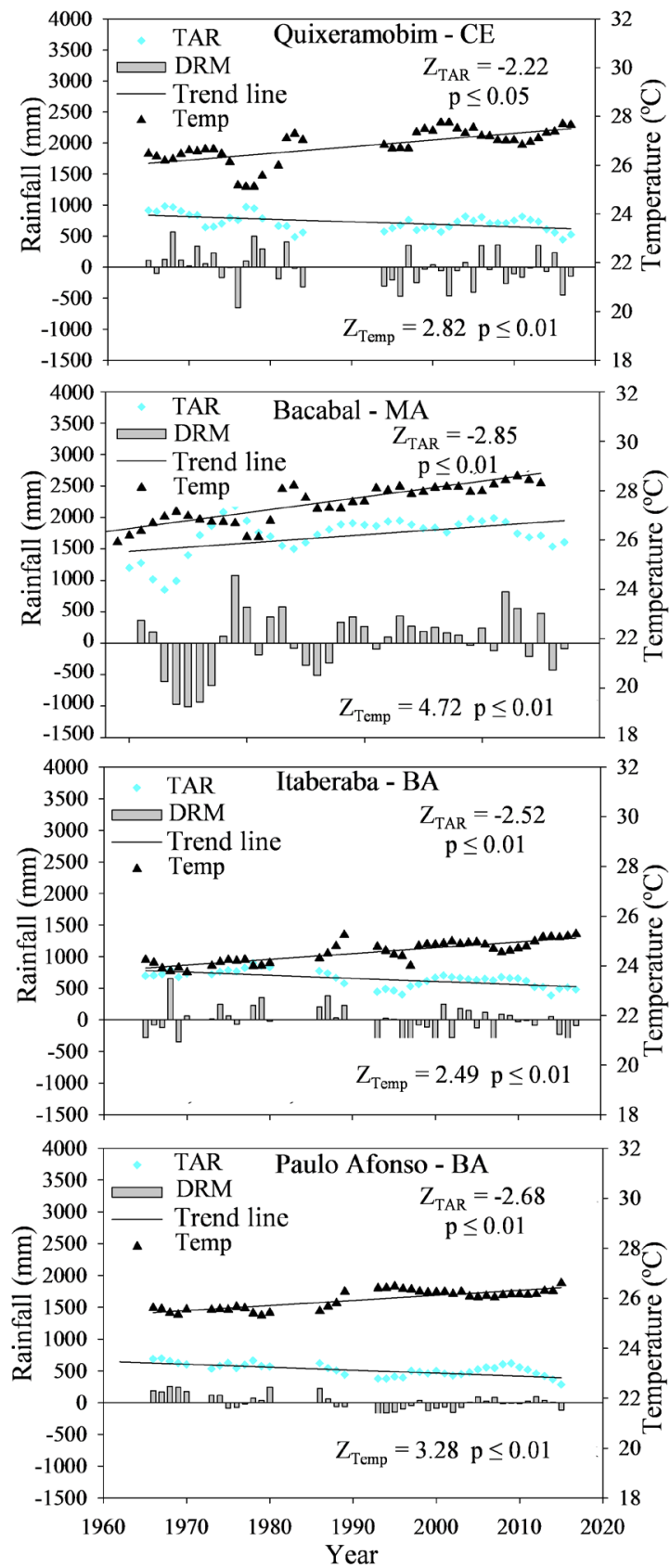

hydraulic structures for flood control and urban drainage (Mello \& Viola, 2013).

The stations within the strip of 150-300 km from the coast showed a trend only at altitudes up to $300 \mathrm{~m}$, both for rainfall and total annual number of rainy days (TANRD), with increase of rainfall in Bacabal, MA, and reduction in Itaberaba, BA, Paulo Afonso, BA, and Quixeramobim, CE (Figure 3). The temperature tended to increase in these stations.

The trends for the stations of Quixeramobim, CE, Itaberaba, BA and Paulo Afonso, BA, until the year 2017 are of reduction in rainfall $(121,148$ and $140 \mathrm{~mm})$ and in rainy days $(3,21$ and 24 days), as well as increase of temperature $\left(0.9,0.69\right.$ and $\left.0.6^{\circ} \mathrm{C}\right)$, respectively.

Asfaw et al. (2018) found a reduction of up to $101 \mathrm{~mm}$ in the average annual rainfall in the Woleka basin in Ethiopia. Xavier et al. (2014) point out that the changes in rainfall

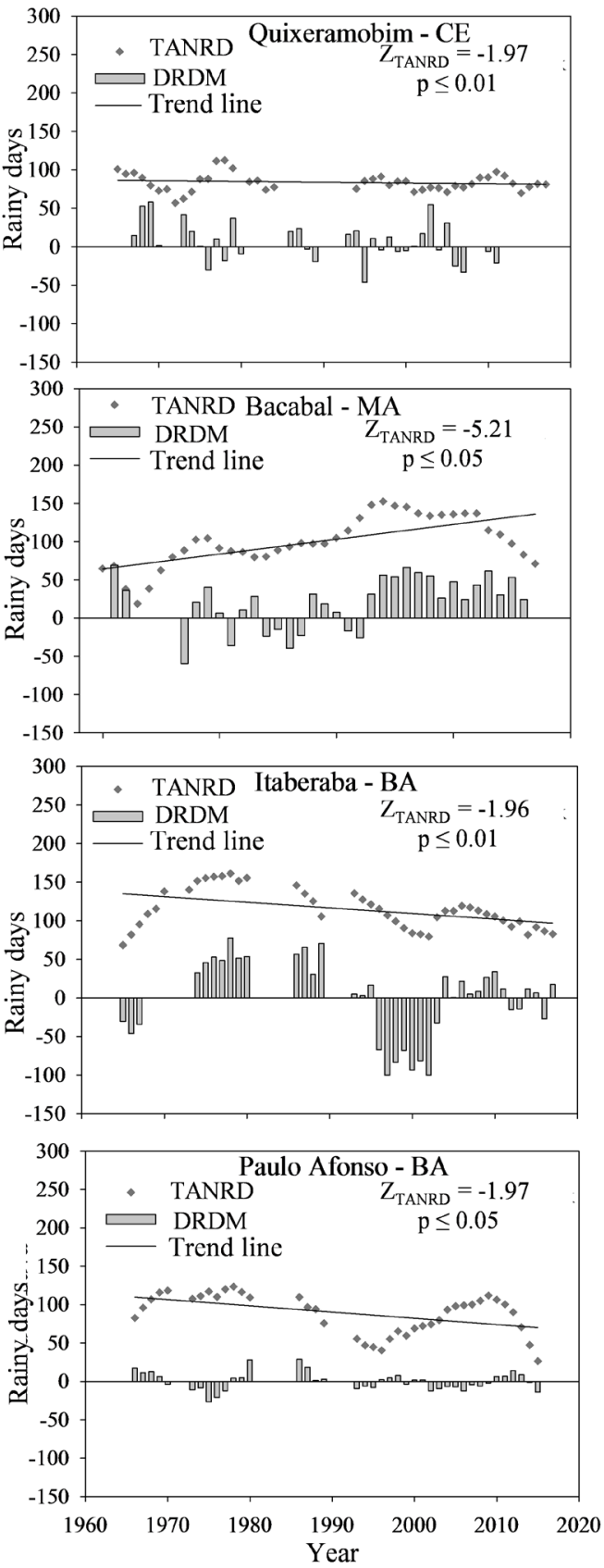

Figure 3. Trend of rainfall (TAR), total annual number of rainy days (TANRD), temperature (Temp), deviations of rainfall from the mean (DRM) and $\mathrm{Z}$ values from the coast of Northeast Brazil between 1961 and 2017 
regimes may threaten the biodiversity of Brazilian biomes, particularly the Caatinga, rich in fauna and flora, which has undergone significant impacts, partly due to the reduction in native vegetation, increasing the Areas Susceptible to Desertification (ASD).

According to Souza et al. (2015), there are more than 1,338 $\mathrm{km}^{2}$ in Northeast Brazil classified as ASD. In these areas, desertification should be regarded as a complex environmental problem, which impacts the support capacity of ecosystems, and where studies analyzing rainfall trends and the number of rainy days are of great relevance to support sustainable environmental management.

The trend of increase and reduction in rainfall was observed for four stations, and the trend for NRD showed the same behavior. A trend of increase in the consecutive dry days was observed for the Agreste Pernambucano and Sertão Pernambucano mesoregions (Nóbrega et al., 2015). Great variability of rainfall and number of rainy days in Northeast Brazil was observed by Silva et al. (2011), who warn about the possible environmental and socioeconomic impact related to rainfed agriculture.

The coefficients of determination $\left(\mathrm{R}^{2}\right)$ of the equations for rainfall and rainy days were low and ranged from 0.02 to 0.48 , but were significant for the trend analysis. These low values are due to high uncertainties in studies on the rainfall regime. Ferreira et al. (2015), Asfaw et al. (2018) and Xu et al. (2018) also found $\mathrm{R}^{2}$ values always below 0.5 for the trend equations.

In the strip of 450-600 km from the coast for altitudes of up to $300 \mathrm{~m}$, only the station of Balsas, MA, showed a trend of increase in NRD and temperature. For the altitude from 300 to $600 \mathrm{~m}$, the station of Correntina, BA, Brazil, showed a trend of reduction in rainfall and increase of temperature (Figure 4).

Rainfall distribution in the Northeast region has an impact on the occurrence and location of extreme events (drought and floods). The more distant from the coast, the higher the rainfall variability and the lower the rainfall values.

The trend of change in the TAR, TANRD, DRM, DRDM from the mean and NRD was not clearly identified in Northeast Brazil, for the studied period, since the stations located on the coast showed a trend only for NRD isolated from rainfall. In the stations of the strip from 150 to $300 \mathrm{~km}$, the trends were verified for number of rainy days, while in the strip from 450 to $600 \mathrm{~km}$ the stations showed isolated trends.

$\mathrm{Xu}$ et al. (2018) also report a lack of clarity in the rainfall trends in different magnitudes of topographic elevation. In addition, changes in the trend magnitudes in sites of low elevation may be associated to the topographic conditions of alluvial valleys and to orographic effects.

The high spatial and temporal variability of rainfall can be observed in the relative difference for rainfall and NRD in all localities, particularly in the strip from 150 to $300 \mathrm{~km}$ (Figure 3).

The different patterns of rainfall and NRD observed, despite having regional trends of increase and decrease in rainfall and rainy days, promoted changes in rainfall intensity for different localities in the context of continentality, and it is necessary to reevaluate water security in the region. Sayemuzzaman \& Jha (2014) and Steinke \& Barros (2015) highlight the importance of understanding the climate, in the aspect of rainfall trend, in order to support agricultural planning and thus mitigate the losses of biodiversity and crop yields and, consequently, alleviate the socioeconomic impacts.

Given the greater complexity in rainfall and NRD patterns, with trends of both increase and decrease and greater variability, observed through the coefficient of variation, classified as low to medium with minimum values (21.3 and $8.7 \%$ ) and maximum values (52.5 and $46.1 \%$ ), respectively, as well as a lower temperature variability, with $\mathrm{CV}$ values ranging from 1.5 to $4.5 \%$ (classified as low) (Table 1), the complementary spatial geostatistical analysis of the future scenarios by kriging was performed only for rainfall and NPD.

The experimental and theoretical semivariograms, fitted and the spatial distribution of rainfall for the current scenario (Rainfall, P - Current and NRD, D - Current) and estimated scenarios for 30 years in the future (Rainfall, $\mathrm{P}-30$ years and NRD, D - 30 years), are shown in Figures 5A and B, respectively. All experimental semivariograms were adequately fitted to the exponential model, with the respective fitting parameters of the semivariogram (nugget effect $(\mathrm{Co})$, sill $\left(\mathrm{C}_{1}\right)$, range (Ao) and coefficients of determination $\left(\mathrm{R}^{2}\right)$ ), showed in Figure 5.

The two semivariograms of rainfall and NRD showed strong spatial dependence. The validation was performed according to the standard deviation of the residual statistics $(0.83,0.75$, 0.78 and 0.83$)$ and for mean errors $(-0.034,-0.047,-0.038$ and -0.047), for rainfall and days until 2017, rainfall and days estimated for 30 years, respectively.

The ranges (Ao) and $R^{2}$ values obtained for rainfall in the current scenario $\left(1338 \mathrm{~km}\right.$ and $\left.\mathrm{R}^{2}=0.81\right)$ were higher than those corresponding to the future scenario $\left(854 \mathrm{~km}\right.$ and $\left.\mathrm{R}^{2}=0.69\right)$. The same behavior was observed for NRD with ranges for the
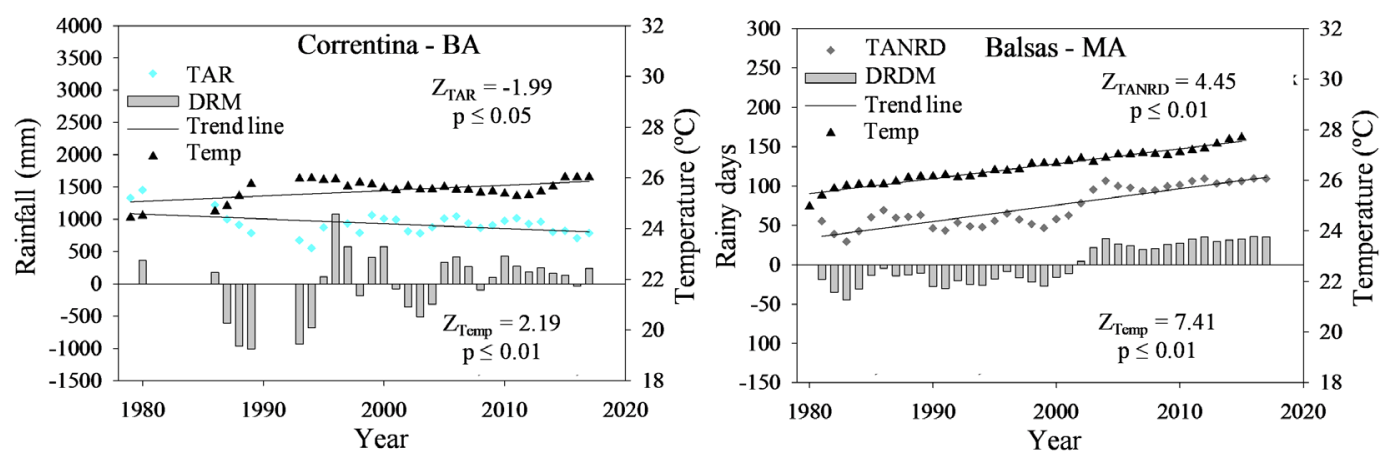

Figure 4. Trend of rainfall (TAR), total annual number of rainy days (TANRD), temperature (Temp), deviations of rainfall from the mean (DRM) and Z values for the strip of 450-600 km from the coast of Northeast Brazil between 1961 and 2017 

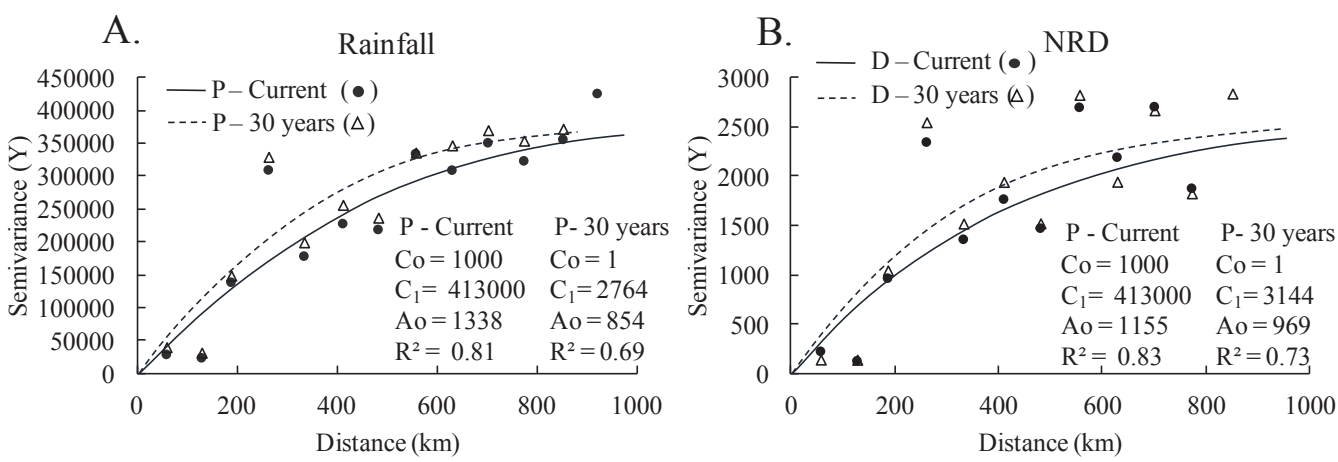

C.

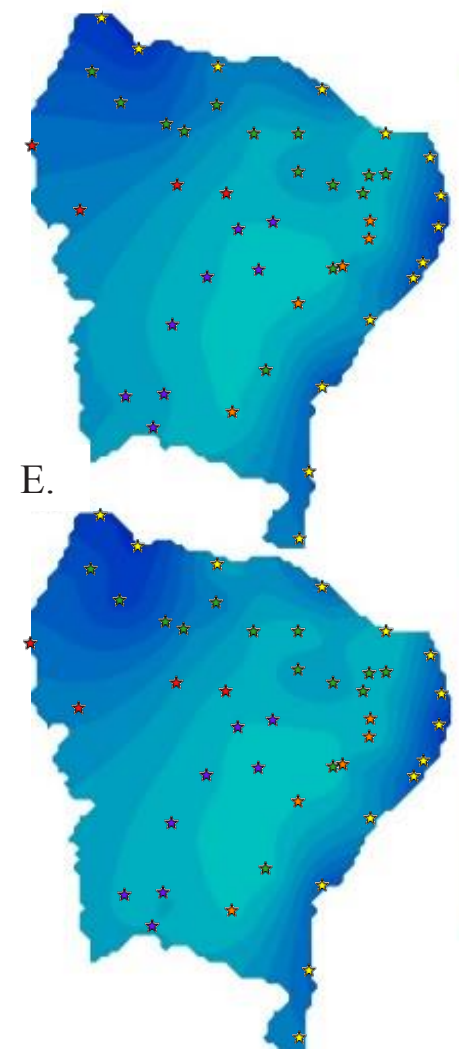

D.

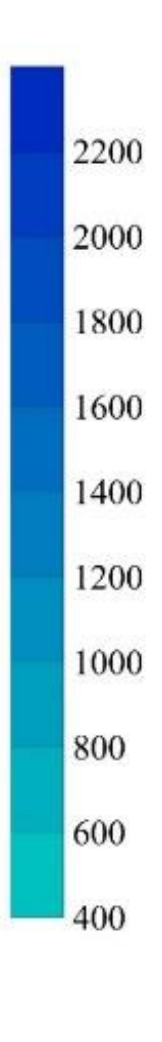

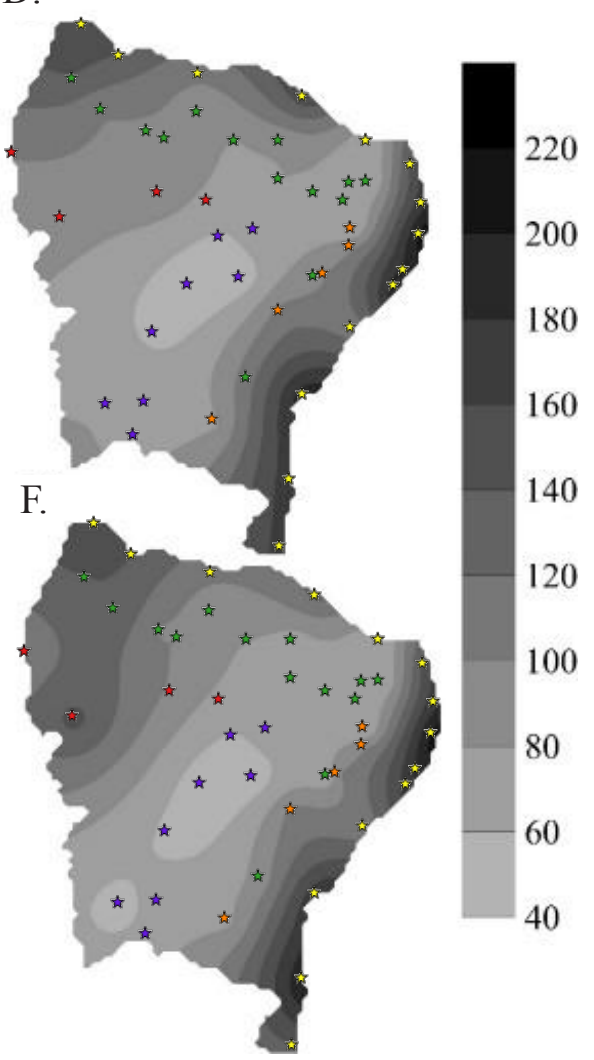

Figure 5. Semivariograms of rainfall (A) and number of rainy days (NRD) (B) for the Brazilian northeast region for the current scenario (1961-2017) and future scenario (1961-2047) and isoline maps for rainfall (mm) in the current (C) and future (E) scenarios and NRD in the current (D) and future (F) scenarios for the Brazilian northeast region, obtained by kriging

current scenario $\left(1155 \mathrm{~km}\right.$ and $\left.\mathrm{R}^{2}=0.83\right)$ and future scenario (969 $\mathrm{km}$ and $\mathrm{R}^{2}=0.73$ ). With the reductions in the ranges for the scenarios of 30 years, the Northeast Brazil will have greater spatial variability of rainfall and NRD, especially in the region encompassing the Sertão. These results demonstrate greater spatial dependence in the current scenario and greater variability in the future scenario.

Silva et al. (2012), studying the rainfall and number of rainy days in Northeast Brazil, observed high variability in the dry and rainy seasons, influencing the agricultural production in the microregions located in the semiarid areas.

Figure 5E, projecting the trend for 2047, shows a reduction in rainfall mainly in the central portion of the Northeast region, in the area encompassing the Sertão in relation to the current scenario (Figure 5C).

The trend of reduction in rainfall accompanies the reduction of rainy days in the current scenario (Figure 5D) for the Northeastern Sertão in relation to the future scenario
(Figure 5F). These results show changes in rainfall patterns more concentrated in the Northeastern Sertão area, which may cause intensification of water deficit.

Assessing the behavior of rainfall, Nóbrega et al. (2016) found a trend of reduction in rainfall in Pernambuco State. The authors also emphasize that the irregular spatial-temporal distribution of rainfall in the Northeastern Sertão is associated to prolonged periods of water restriction and negatively influences the water level of rivers, turning this region more vulnerable to extreme events.

\section{Conclusions}

1. The central portion of the Northeast region has higher trend of variation in rainfall, number of rainy days and temperature.

2. There will be greater spatial variability of rainfall and number of days without rain for Northeast Brazil, especially for the central region encompassing the Sertão. 
3. The trend analysis shows reduction in the number of rainy days on the Northeastern coast, while in the central region there is reduction in both rainfall and number of rainy days, and trend of increase in temperature for regions more distant from the coast.

4. Greater increases in temperature and reductions in total annual rainfall and number of rainy days are observed in Northeast Brazil.

\section{ACKNOWLEDgMENTS}

To the Conselho Nacional de Desenvolvimento Científico e Tecnológico (CNPq), to the Financiadora de Estudos e Projetos (FINEP) and to the Fundação de Amparo à Ciência e Tecnologia do Estado de Pernambuco (FACEPE - APQ-0300$5.03 / 17$ and IBPG-1758-5.03/15) for the support to the study.

\section{Literature Cited}

Asfaw, A.; Simane, B.; Hassen, A.; Bantider, A. Variability and time series trend analysis of rainfall and temperature in northcentral Ethiopia: A case study in Woleka sub-basin. Weather and Climate Extremes, v.19, p.29-41, 2018. https://doi.org/10.1016/j.wace.2017.12.002

Back, A. J.; Oliveira, J. L. R.; Henn, A. Relações entre precipitações intensas de diferentes durações para desagregação da chuva diária em Santa Catarina. Revista Brasileira de Engenharia Agrícola e Ambiental, v.16, p.391-398, 2012. https://doi.org/10.1590/S141543662012000400009

Buriol, G. A.; Estefanel, V.; Chagas, A. C. de. Distribuição geográfica da precipitação pluviométrica no Estado do Rio Grande do Sul. Revista Eletrônica Vidya, v.24, p.133-145, 2004.

Cambardella, C. A.; Moorman, T. B.; Novak, J. M.; Parkin, T. B.; Karlen, D. L.; Turco, R. F.; Konopka, A. E. Field-scale variability of soil properties in Central Iowa Soils. Soil Science Society of America Journal, v.58, p.1501-1511, 1994. https://doi.org/10.2136/ sssaj1994.03615995005800050033x

Carretas, F. L. Sistema automático de baixo custo para a medição da altura da base das nuvens e da visibilidade atmosférica. Évora: Universidade de Évora, 2014. 108p. Dissertação Mestrado

Fall, S.; Watts, A.; Nielsen-Gammon, J.; Jones, E.; Niyogi, D.; Christy, J. R.; Pielke, R. A. Analysis of the impacts of station exposure on the U.S. Historical climatology network temperatures and temperature trends. Journal of Geophysical Research: Atmospheres, v.116, p.115, 2011. https://doi.org/10.1029/2010JD015146

Ferreira, D. H. L.; Penereiro, J. C.; Fontolan, M. R. Análises estatísticas de tendências das séries hidro-climáticas e de ações antrópicas ao longo das sub-bacias do Rio Tietê. Holos, v.2, p.50-68, 2015. https://doi.org/10.15628/holos.2015.1455

INMET - Instituto Nacional de Meteorologia. Banco de Dados Meteorológicos para Ensino e Pesquisa - BDMEP. Available at: < http://www.inmet.gov.br/portal/index.php?r=bdmep/bdmep) $>$. Accessed in: Jun. 2018.

IPCC - Intergovernmental Panel on Climate Change. The physical science basis (AR5). Contribution of working group I to the fifth assessment report. Cambridge University Press, Cambridge, United Kingdom and New York, NY, USA, 2013. 1535p.

Mahlstein, I.; Knutti, R. Regional climate change patterns identified by cluster analysis. Climate Dynamics, v.35, p.587-600, 2010. https://doi.org/10.1007/s00382-009-0654-0
Marcuzzo, F.; Faria, T. G.; Pinto Filho, R. de F. Chuvas no Estado de Goiás: Análise histórica e tendência futura. Revista Acta Geográfica, v.6, p.125-137, 2012. https://doi.org/10.5654/ actageo2012.0612.0007

Mello, C. R. de; Viola, M. R. Mapeamento de chuvas intensas no Estado de Minas Gerais. Revista Brasileira de Ciência do Solo, v.37, p.3744, 2013. https://doi.org/10.1590/S0100-06832013000100004

Montenegro, A. A. de A.; Montenegro, S. M. G. L. Variabilidade espacial de classes de textura, salinidade e condutividade hidráulica de solos em planície aluvial. Revista Brasileira de Engenharia Agrícola e Ambiental, v.10, p.30-37, 2006. https:// doi.org/10.1590/S1415-43662006000100005

Montenegro, A. A. de A.; Ragab, R. Hydrological response of a Brazilian semiarid catchment to different land use and climate change scenarios: Modelling study. Hydrological Processes, v.24, p.2705-2723, 2010. https://doi.org/10.1002/hyp.7825

Nóbrega, R. S.; Farias, R. F. de L.; Santos, C. A. C. Variabilidade temporal e espacial da precipitação pluviométrica em Pernambuco através de índices de extremos climáticos. Revista Brasileira de Meteorologia, v.30, p.171-180, 2015. https://doi.org/10.1590/0102778620130624

Nóbrega, R. S.; Santiago, G. A. C. F.; Soares, D. B. Tendências do controle climático oceânico sob a variabilidade temporal da precipitação no Nordeste do Brasil. Revista Brasileira de Climatologia, v.18, p.276-292, 2016. https://doi.org/10.5380/ abclima.v18i0.43657

Pingale, S. M.; Khare, D.; Jat, M. K.; Adamowski, J. Spatial and temporal trends of mean and extreme rainfall and temperature for the 33 urban centers of the arid and semi-arid state of Rajasthan, India. Atmospheric Research, v.138, p.73-90, 2014. https:/doi. org/10.1016/j.atmosres.2013.10.024

Pinheiro, A.; Graciano, R. L. G.; Severo, D. L. Tendência das séries temporais de precipitação da região sul do Brasil. Revista Brasileira de Meteorologia, v.28, p.281-290, 2013. https://doi. org/10.1590/S0102-77862013000300005

Sayemuzzaman, M.; Jha, M. K. Seasonal and annual precipitation time series trend analysis in North Carolina, United States. Atmospheric Research, v.137, p.183-194, 2014. https://doi. org/10.1016/j.atmosres.2013.10.012

Sen, P. K. Estimates of the regression coefficient based on Kendall's Tau. Journal of American Statisitcs Association, v.63, 1379-1389, 1968. https://doi.org/10.1080/01621459.1968.10480934

Silva, B. M.; Montenegro, S. M. G. L.; Silva, F. B. da; Araújo Filho, P. F. de. Chuvas intensas em localidades do Estado de Pernambuco. Revista Brasileira de Recursos Hídricos, v.17, p.135-147, 2012. https://doi.org/10.21168/rbrh.v17n3.p135-147

Silva, V. P. R. da; Pereira, E. R. R.; Azevedo, P. V. de; Sousa, F. de A. S.; Sousa, I. F. de. Análise da pluviometria e dias chuvosos na região Nordeste do Brasil. Revista Brasileira de Engenharia Agrícola e Ambiental, v.15, p.131-138, 2011. https://doi.org/10.1590/S141543662011000200004

Souza, B. I. de; Artigas, R. C.; Lima, E. R. V. de. Caatinga e desertificação. Mercator, v.14, p.131-150, 2015. https://doi. org/10.4215/RM2015.1401.0009

Steinke, T. E.; Barros, J. R. Tipos de tempo e desastres urbanos no Distrito Federal entre 2000 e 2015. Revista Brasileira de Geografia Física, v.8, p.1435-1453, 2015. https://doi.org/10.5935/19842295.20150079 
Sun, C.; Ma, Y. Effects of non-linear temperature and precipitation trends on Loess Plateau droughts. Quaternary International, v.372, p.175-179, 2015. https://doi.org/10.1016/j.quaint.2015.01.051

Warrick, A. W.; Nielsen, D. R. Spatial variability of soil physical properties in the field. In: Hillel, D. (ed.). Applications of soil physics. New York: Academic, 1980. Cap.2, p.319-344. https:// doi.org/10.1016/B978-0-12-348580-9.50018-3

WMO - World Meteorological Organization. Calculation of monthly and annual 30-year standard normals: Prepared by a meeting of experts. Washington, D. C., USA, (Geneva: WMO). 1989.
Xavier, D. R.; Barcellos, C.; Barros, H. da S.; Magalhães, M. de A. F. M.; Matos, V. P. de; Pedroso, M. de M. Organização, disponibilização e possibilidades de análise de dados sobre desastres de origem climática e seus impactos sobre a saúde no Brasil. Ciência \& Saúde Coletiva, v.19, p.3657-3668, 2014. https://doi.org/10.1590/141381232014199.00992014

Xu, M.; Kang, S.; Wu, H.; Yuan, X. Detection of spatio-temporal variability of air temperature and precipitation based on long-term meteorological station observations over Tianshan Mountains, Central Asia. Atmospheric Research, v.203, p.141-163, 2018. https://doi.org/10.1016/j.atmosres.2017.12.007 